\title{
ANALISIS MOLEKULER DNA ALGA MERAH (RHODOPHYTA) Kappaphycus sp.
}

\author{
(Molecular Analysis of DNA Red Algae (Rhodophyta) Kappaphycus sp.)
}

\section{Manikmayang Annisaqois ${ }^{1 *}$, Grevo S. Gerung ${ }^{1}$, Stenly Wullur ${ }^{1}$, Deiske A. Sumilat ${ }^{1}$, Billy T. Wagey ${ }^{1}$, Stephanus V. Mandagi ${ }^{2}$}

1. Program Studi Ilmu Kelautan, Fakultas Perikanan dan Ilmu Kelautan, Universitas Sam Ratulangi, Manado.

2. Program Studi Manajemen Sumberdaya Perairan, Fakultas Perikanan dan IImu Kelautan, Universitas Sam Ratulangi, Manado.

*e-mail : manikmayangannisa@gmail.com

Indonesia reported has 555 species or $6.24 \%$ from total species of macroalgae in the world that already identified. Seaweed from red algae class (Rhodophyceae) is the most abudance plant in the Indonesia waters or around 452 genera. Seaweed from red algae especially Kappaphycus sp. has high level of morphology plasticity so that conventional indentification technique using morphology character indicator frequently not optimal on identify macroalgae species. This research is the first stage on molecular analysis of red algae Kappaphycus sp. The methods of DNA Kappaphycus sp. extraction using modified CTAB methods (Doyle \& Doyle, 1987; Allen, 2006; Nugroho et al., 2015). Rbcl gene amplified using PCR with several primer combination. The success of DNA extraction and gene rbcL amplification observe by UV transilluminator after gel electrophoresis. The appearance of band DNA using rbcL primer F-7 (for) and R-753 (rev) visualized around 1400-1600 bp and from rbcL primer F-577 (for) and R753 (rev) visualized around 900-1400 bp. That become success indicator of gene rbcL amplification from red algae Kappaphycus sp.

Keywords: Kappaphycus sp., Extraction, DNA, CTAB, gene rbcL

Indonesia dilaporkan memiliki sebanyak 555 spesies atau sekitar $6.24 \%$ dari total jumlah spesies rumput laut dunia yang teridentifikasi saat ini. Rumput laut dari kelas alga merah (Rhodophyceae) menempati urutan terbanyak dari jumlah jenis yang tumbuh di perairan laut Indonesia yaitu sekitar 452 jenis. Rumput laut dari kelas alga merah ini terutama dari jenis Kappaphycus sp. memiliki tingkat plastisitas morfologi yang tinggi sehingga teknik identifikasi konvensional menggunakan indikator karakter morfologi sering kurang maksimal dalam penelusuran identitas spesies rumput laut. Penelitian ini merupakan tahapan awal dalam rangkaian analisa molekuler rumput laut jenis Kappaphycus sp. Dalam penelitian ini, ekstraksi DNA Kappaphycus sp. dilakukan dengan metode CTAB (Doyle and Doyle, 1987; Allen, 2006; Nugroho et al., 2015) yang dimodifikasi. Gen rbcL diamplifikasi pada PCR menggunakan beberapa pasangan primer. Keberhasilan proses ekstraksi DNA genomik dan amplifikasi gen $r b c L$ dari Kappaphycus sp. dideteksi melalui UV transilluminator setelah melalui proses elektroforesis gel. Munculnya pita DNA pada penggunaan primer rbcL F-7 (for) dan R-753 (rev) yang menghasilkan panjang pita DNA antara 1400-1600 bp dan primer rbcL F-577 (for) dan R753 (rev) yang menghasilkan panjang pita DNA antara 900-1400 bp menjadi indikasi keberhasilan amplifikasi gen $r c b L$ pada rumput laut Kappaphycus sp.

Kata kunci: Kappaphycus sp., Ekstraksi, DNA, CTAB, gen rbcL

\section{PENDAHULUAN}

Indonesia adalah negara

kepulauan yang terletak di antara Benua Asia dan Benua Australia serta Samudra Pasifik dan Samudra Hindia. Posisi geografis inilah yang menjadi salah satu faktor penyebab tingginya keberagaman spesies rumput laut di Indonesia. Sebagaimana dilaporkan, Indonesia yang memiliki sekitar 17.000 pulau, menjadi tempat yang cocok untuk pertumbuhan rumput laut karena 
garis pantainya yang panjang (Gerung, 2001). Rumput laut dari kelas alga merah (Rhodophyceae) menempati urutan terbanyak dari jumlah jenis yang tumbuh di perairan laut Indonesia yaitu sekitar 452 jenis (Winarno, 1996).

Identifikasi spesies dari kelas alga merah terutama dari jenis Kappaphycus yang banyak dilakukan saat ini menggunakan teknik konvensional berbasis karakter morfologi. Teknik konvensional ini sering kurang maksimal digunakan dalam identifikasi spesies, bahkan pada kasus-kasus tertentu banyak menimbulkan kekeliruan sehubungan dengan tingkat plastisitas morfologi yang tinggi dari jenis alga ini (Zuccarello et al., 2006).

Karakter molekuler dapat dimanfaatkan untuk mengetahui variasi gen sehingga perbedaan antar jenis dapat dilihat dengan jelas. Pendekatan molekuler juga memberi peluang untuk menemukan karakter suatu jenis. Jika informasi batasan suatu jenis tersedia maka variasi plasma-nutfah dapat diakses secara lebih efisien dan efektif baik untuk pemuliaan tanaman maupun kegiatan konservasi. Pada metode lain yang berbeda, pengaplikasian teknik molekuler pada alga masih memiliki banyak kesulitan terutama dalam mendapatkan jumlah dan kualitas DNA maupun hasil amplifikasi gen target yang ideal untuk analisis molekuler selanjutnya (Anggraeni et al., 2008).

Dalam penelitian ini, telah dilakukan suatu studi awal analisis DNA taksonomi alga merah Kappaphycus sp. yang difokuskan pada pengembangan teknik DNA dan amplifikasi gen $r c b L$ sebagai gen target untuk identifikasi spesies alga merah ini.

Adapun tujuan dari penelitian ini adalah menentukan keberhasilan ekstraksi DNA rumput laut Kappaphycus sp. menggunakan metode CTAB (Doyle and Doyle, 1987; Allen, 2006; Nugroho et al., 2015) yang dimodifikasi dan mengamplifikasi gen $r c b L$ sebagai gen target identifikasi spesies Kappaphycus sp. dengan menggunakan beberapa kombinasi pasangan primer.

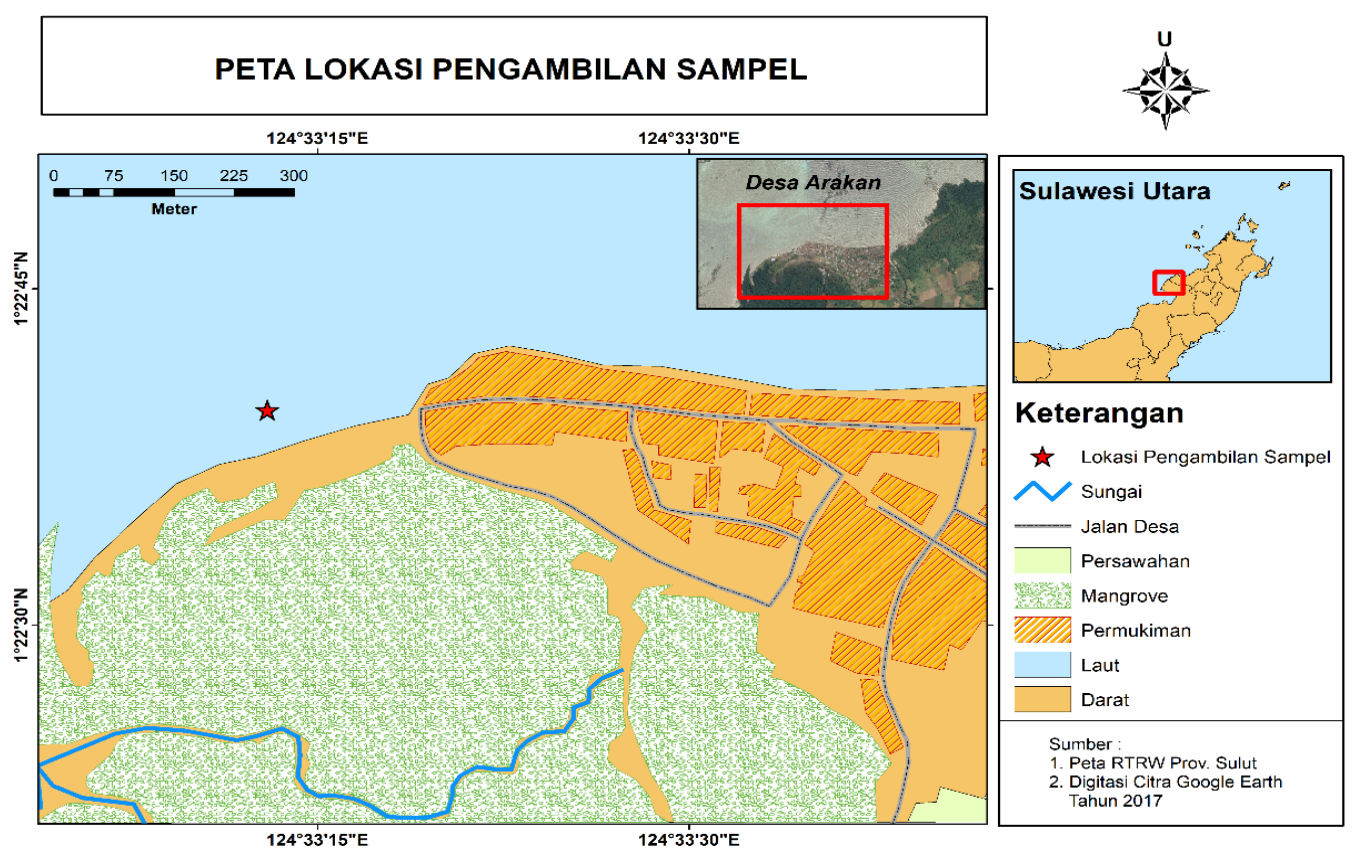

Gambar 1. Peta pengambilan sampel. 


\section{METODE PENELITIAN}

\section{Lokasi Pengambilan Sampel}

Pengambilan sampel dilakukan di Desa Arakan (Gambar 1), selanjutnya ekstraksi DNA rumput laut dan analisis molekuler dilakukan di Laboratorium Biologi Molekuler dan Farmasetika Fakultas Perikanan dan IImu Kelautan Universitas Sam Ratulangi Manado.

\section{Sterilisasi Alat}

Alat-alat yang digunakan dalam penelitian ini seperti gunting, ependorf, tube, tip dan mikrotip, disterilisasi dalam autoklaf pada suhu $121^{\circ} \mathrm{C}$ selama 15 menit (sterilisasi basah).

\section{Ekstraksi DNA Kappaphycus sp.}

\section{Reagen dan Extraction Buffer}

Proses pembuatan reagen dan extraction buffer yaitu, $1 \mathrm{M}$ Tris, $5 \mathrm{M} \mathrm{NaOH}$, 0,5M EDTA, $5 \mathrm{M} \mathrm{NaCl}$, TE Buffer, 3M NaAc, CTAB, $\mathrm{dH}_{2} \mathrm{O}, \quad \mathrm{PVP}, \quad \beta$-mercaptoetanol, vitamin $\mathrm{C}$.

\section{Lisis Sel}

Sampel rumput laut terlebih dahulu dibilas menggunakan $\mathrm{dH}_{2} \mathrm{O}$ dan dipotong hingga mendapatkan berat sampel sebanyak 0,15 g. Sampel kemudian digerus menggunakan mortar dan pestel steril sambil ditambahkan sebanyak $1 \mathrm{ml}$ extraction buffer selama penggerusan. Sampel yang telah digerus selanjutnya pindahkan ke ependorf tube dan disentrifugasi dengan kecepatan 12.000 rpm selama 4 menit.

\section{Ekstraksi DNA}

Hasil sentrifugasi didapatkan dalam bentuk lapisan supernatan dan presipitan. Lapisan supernatan dibuang dan ependorf yang berisi lapisan presipitan kembali ditambahkan sebanyak $700 \mu$ l extraction buffer. Proses ini diulang sebanyak 4 kali dan untuk pengulangan terakhir supernatan tidak dibuang. Selanjutnya sampel diinkubasi 3 jam pada suhu $65^{\circ} \mathrm{C}$ dengan interval 15 menit sekali dihomogenkan dengan menggunakan vortex. Hasil ekstraksi yang telah diinkubasi tersebut lalu disentrifugasi dengan kecepatan $13.500 \mathrm{~g}$ selama 10 menit hingga menghasilkan 3 lapisan dalam tube.

\section{Presipitasi DNA}

Lapisan supernatan pada bagian paling atas tube selanjutnya dipisahkan pada sebuah tabung ependorf yang baru dan ditambahkan Fenol-Kloroform-Isoamil Alkohol dengan perbandigan 25:24:1 sebanyak $800 \mu \mathrm{l}$ diinkubasi selama 30 menit pada suhu ruangan $\left( \pm 25^{\circ} \mathrm{C}\right)$ didalam Laminar Air Flow lalu disentrifugasi selama 10 menit dengan kecepatan $13.500 \mathrm{~g}$.

Setelah terbentuk tiga lapisan pada tube, lapisan supernatan pada bagian paling atas tube selanjutnya dipisahkan pada sebuah tabung ependorf yang baru dan ditambahkan 2 - propanol dingin sebanyak $800 \mu \mathrm{l}$ dan dicampurkan dengan menginvert tube. Selanjutnya disimpan di Laminar Air Flow selama 10 menit pada suhu ruangan $\left( \pm 25^{\circ} \mathrm{C}\right)$ dan disentrifugasi dengan kecepatan $13.500 \mathrm{~g}$ selama 10 menit, kemudian supernatan dibuang. TE Buffer sebanyak $250 \mu$ litambahkan ke tube ependorf kemudian diinkubasi kembali di Thermo-block selama 30 menit pada suhu $37^{\circ} \mathrm{C}$ dan $3 \mathrm{M} \mathrm{NaAc}$, sebanyak $25 \mu$ ditambahkan ke tube ependorf kemudian dicampurkan dengan menginvert tube.

\section{Purifikasi DNA}

Etanol dingin $70 \%$ sebanyak $600 \mu \mathrm{l}$ ditambahkan kedalam tube dan invert sebanyak satu kali. Tube kemudian disimpan di Laminar Air Flow selama 10 menit pada suhu ruangan $\left( \pm 25^{\circ} \mathrm{C}\right)$ lalu disentrifugasi pada kecepatan $13.500 \mathrm{~g}$ selama 10 menit kemudian supernatan dibuang. Etanol dingin sebanyak $500 \mu \mathrm{l}$ ditambahkan, kemudian tube diinvert sebanyak satu kali lalu disentrifugasi dengan kecepatan $13.500 \mathrm{~g}$ selama 10 
menit kemudian supernatan dibuang. Presipitan yang didapatkan kemudian dikeringkan di Laminar Air Flow dengan cara meletakan tisu lalu tube dibuka dan kemudian dibalik dan didiamkan selama 2 jam. TE Buffer sebanyak $25 \mu \mathrm{l}$ ditambahkan ke dalam tube. Selanjutnya sampel dapat disimpan di kulkas sebelum digunakan untuk proses selanjutnya.

\section{Elekroforesis Gel}

\section{Pembuatan Gel Agarose}

Gel agarose 1\% dibuat dengan melarutkan 0,3 gr bubuk agarose, $30 \mathrm{ml}$ 10x TBE buffer dan 0,6 $\mu$ l cyber green DMSO kemudian dipanaskan dan dituangkan ke dalam cetakan gel tray dan biarkan selama \pm 30 menit hingga mengeras menjadi gel.

\section{Elektroforesis Gel}

Proses elektroforesis dilakukan dengan mencampurkan sebanyak $4 \mu \mathrm{l}$ DNA sampel dengan $1 \mu \mathrm{l} 10 \mathrm{x}$ Sampel Loading Buffer diatas parafilm, kemudian dimasukan ke dalam sumur gel elektroforesis. Sebanyak $2 \mu \mathrm{l} 100 \mathrm{bp}$ ladder DNA marker dimasukan pula ke dalam sumur gel elektroforesis yang berbeda sebagai penanda berat molekul. Proses elektroforesis dilakukan menggunakan larutan 1x TBE buffer dengan tegangan listrik 80 volts selama 30 menit.

\section{Visualisasi dengan UV- Transilluminator}

Setelah proses elektroforesis selesai, gel kemudian diangkat dan letakan di atas UV-transilluminator untuk diamati keberadaan pita DNAnya dengan menggunakan kaca mata pelindung saat melakukan ekspos gel pada sinar UV. Hasil elektroforesis DNA ekstrak DNA genom Kappaphycus sp. kemudian didokumentasikan dengan kamera.

\section{Amplifikasi DNA}

Proses amplifikasi gen dilakukan dengan menggunakan beberapa kombinasi primer rbcL sebagai gen target amplifikasi. Tahap amplifikasi gen yang dilakukan pertama adalah membuat campuran reaksi yang diisi dalam tabung reaksi khusus untuk PCR. Tabung reaksi disentrifugasi selama 30 menit kemudian mesin PCR dinyalakan. Masing-masing tabung dimasukkan ke dalam PCR.

Program Heater lid diatur pada suhu $99^{\circ} \mathrm{C}$. Program siklus yang akan digunakan dengan pengaturan suhu pre-denaturasi $95^{\circ} \mathrm{C}$ selama 6 menit, denaturasi $95^{\circ} \mathrm{C}$ selama 30 detik (35 siklus), annealing $52^{\circ} \mathrm{C}$ selama 30 detik, elongasi $72^{\circ} \mathrm{C}$ selama 30 detik, dan post-elongasi $72^{\circ} \mathrm{C}$ selama 10 menit. Tahap amplifikasi gen selesai dan dilanjutkan pada tahap elektroforesis gel untuk melihat keberhasilan dari tahap amplifikasi gen.

\section{HASIL DAN PEMBAHASAN}

\section{Ekstraksi DNA Kappaphycus sp.}

Dewasa ini telah banyak tersedia produk ekstraksi DNA komersil diantaranya innuprep DNA minikit (AnalytikJena), Qiagen DNAeasy kit dan Innuprep plant DNA kit. Beberapa laporan penelitian sebelumnya, menunjukan keberhasilan penggunaan kit-kit komersil tersebut untuk mendapatkan ekstrak genomik DNA biota laut (Mopay et al., 2017; Sahari et al., 2017; Wehantouw et al., 2017; Tindi et al., 2017 dan Peloa et al., 2016). Hasil yang berbeda pada penelitian yang dilakukan oleh Hengkengbala (2017) menunjukan bahwa penggunaan kit komersil tersebut tidak berhasil digunakan dalam proses ekstraksi DNA genomik rumput laut jenis Kappaphycus sp.

Dalam penelitian ini telah digunakan teknik ekstraksi DNA genomik Kappaphycus sp. menggunakan prosedur CTAB yang telah dimodifikasi dari Doyle and Doyle (1987), Allen (2006), dan Nugroho et al. (2015) dengan membuat buffer ekstraksi yang terdiri dari campuran $1 \mathrm{M}$ Tris, $5 \mathrm{M} \mathrm{NaCl}, 0.5 \mathrm{M}$ EDTA, CTAB, $\mathrm{dH}_{2} \mathrm{O}$, PVP 90, $\beta$-mercaptoetanol, Vitamin 


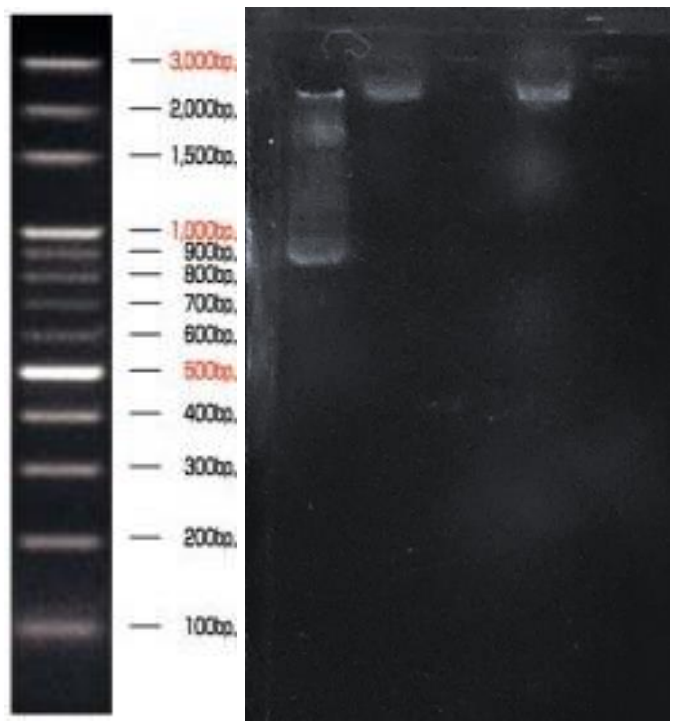

Gambar 2. Hasil Elektroforesis DNA Kappaphycus sp. yang telah melalui proses modifikasi metode ekstraksi DNA menggunakan teknik CTAB.

C 500 gr. Penggunaan PVP dan $\beta$ mercaptoetanol dalam penelitian ini mengikuti prosedur dari Doyle dan Doyle (1987) akan tetapi, hasil ekstrak DNA genomik Kappaphycus sp. masih tercampur dengan bahan lain sehingga membentuk gel.

Penambahan PVP dan $\beta$ mercaptoetanol berfungsi untuk penghilangan senyawa fenolik. Kedua senyawa ini akan mengikat senyawa fenolik dan membantu dalam penghilangan senyawa fenol (Angeles et al., 2005). Dalam penelitian ini telah dilakukan pencucian hasil DNA genomik sebanyak 5 kali untuk mendapatkan DNA genomik murni.

Hasil visualisasi DNA genomik Kappaphycus sp. menggunakan UV transilluminator setelah melalui beberapa tahapan modifikasi prosedur CTAB ditampilkan pada Gambar 2.

\section{Amplifikasi DNA Kappaphycus sp.}

Hasil ekstraksi DNA genomik Kappaphycus sp. menggunakan prosedur CTAB telah digunakan sebagai DNA template dalam proses amplifikasi $\mathrm{g}{ }^{`} n$ rbcL

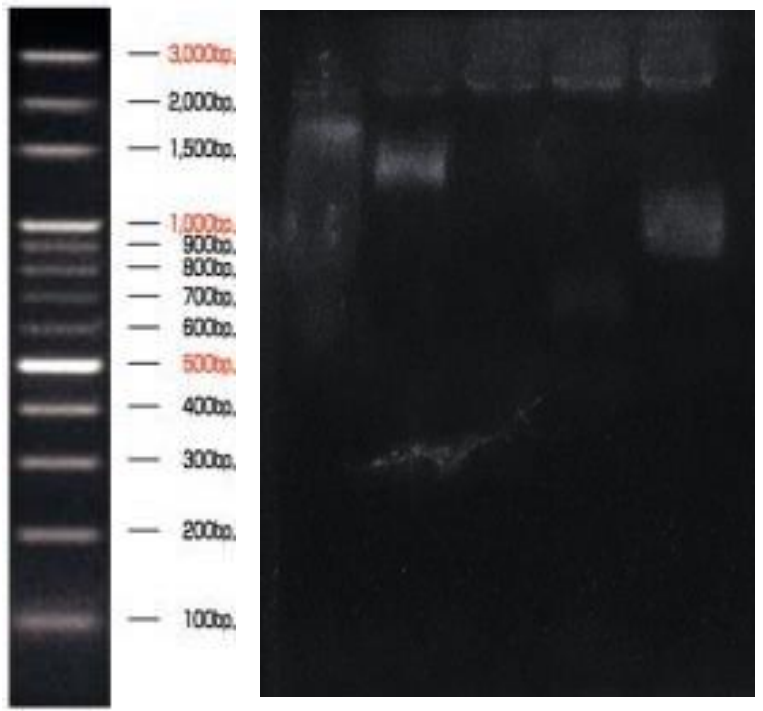

Gambar 3. Hasil amplifikasi gen rcbL menggunakan pasangan primer 1) primer F-7 (for) dan R-753 (rev), 2) primer F-577 (for) dan R-rbcS (rev), 3) primer F-7 (for) dan R-rbcS (rev) dan 4) primer F-577 (for) dan R-753 (rev).

menggunakan kombinasi pasangan primer $\begin{array}{lllll}\text { antara } & \text { F-7 (for) dan R-753 (rev) }\end{array}$ menghasilkan pita pada gel elektroforesis yang muncul pada posisi sekitar 14001600 bp. Munculnya pita DNA pada gel elektroforesis ditemukan pula pada kombinasi pasangan primer antara F-577 (for) dan R-753 (rev) dengan pita DNA pada pada posisi 900-1400 bp. Sedangkan kombinasi primer antara F-577 (for) dan RrbcS (rev) serta primer F-7 dan R-rbcS (rev) tidak teramati munculnya pita DNA pada gel elektroforesis (Gambar 3).

Hasil amplifikasi tersebut diatas mendukung apa yang ditulis oleh Rychlik et al. (1990) dalam Hengkengbala (2017) yang menyatakan bahwa pemilihan primer yang cocok merupakan salah satu parameter yang mempengaruhi keberhasilan proses amplifikasi menggunakan PCR.

\section{KESIMPULAN}

Ekstraksi DNA merupakan tahapan paling penting dalam analisis molekuler karena menjadi penentu dalam mendapatkan kualitas DNA yang baik. 
Proses ekstraksi DNA dibagi menjadi 4 tahapan, yaitu: lisis, ekstraksi, presipitasi dan purifikasi.

Penggunaan primer reverse R-753 dengan forward F-7 dan primer reverse R753 dengan forward F-577 dalam penelitian ini merupakan salah satu pasangan primer yang bisa digunakan untuk mengamplifikasi alga jenis Kappaphycus sp. karena penampakan pita hasil visualisasi dapat terlihat dengan jelas. Walaupun dari hasil amplifikasi yang didapatkan menunjukan bahwa tidak semua pasangan primer rbcL untuk mengamplifikasi DNA Kappaphycus sp. berhasil.

\section{DAFTAR PUSTAKA}

Allen, G.C., Flores-Vergara, M.A., Krasynanski, S., Kumar, S., Thompson, W.S. 2006. A modified protocol for rapid DNA isolation from plant tissues using cetyltrimethylammonium bromide. Nature Protocols, 1(5):2320-2325

Anggraeni, S.R., Sudarsono, Soedharma, D. 2008. Karakterisasi Genetika Rumput Laut Eucheuma spp. dari Tiga Daerah Di Indonesia. Jurnal Bionatura. 10(3):196-208.

Doyle dan Doyle, 1987. CTAB/ChloroformIsoamyl Alcohol DNA Extraction Protocol.

Gerung, G.S. 2001. Study on Indonesian Gracilariaceae. Ph.D. Tesis. Hokkaido University, Graduate School of Fisheries Science. Hokkaido, Japan. p 312..

Hengkengbala, I.R. 2017. Analisis Molekuler Beberapa Jenis Alga. Tesis. Fakultas Perikanan dan IImu Kelautan. UNSRAT.

Mopay, M., Wullur, S., Kaligis, E. 2017. Identifikasi Molekuler Sirip Ikan Hiu yang Didapat dari Pengepul Sirip
Di Minahasa. Jurnal Pesisir dan Laut Tropis.1(2):1-7.

Nugroho, K., Terryana, R.T., Lestari, P. 2015. Optimasi Metode Isolasi DNA pada Jatropha spp. Jurnal Agroteknologi. 5(2):15-22.

Peloa, A., Wullur, S., Sinjal, C.A. 2015. Amplifikasi Gen Cytochrome Oxidase Subunit I (COI) dari Sampel Sirip Ikan Hiu dengan Menggunakan Beberapa Pasangan Primer. Jurnal Pesisir dan Laut Tropis. 1(1):37-42.

Sahari, J., Rimper, J., Wullur, S. 2017. Identifikasi Molekul Rotifera Brachionus sp. Asal Perairan Tumpaan, Minahasa Selatan. Jurnal Pesisir dan Laut Tropis. 1(1):56-61.

Tindi, M., Mamangkey, N.G.F., Wullur, S. 2017. DNA Barcode dan Analisis Filogenik Molekuler Beberapa Jenis Bivalvia Asal Perairan Sulawesi Utara Berdasarkan Gen COI. Jurnal Pesisir dan Laut Tropis. 1(2): 32-38.

Wehantouw, A., Ginting, E.L., Wullur, S. 2017. Identifikasi Sirip Ikan Hiu Yang Didapat dari Pengumpul di Minahasa Tenggara Menggunakan DNA Barcode. Jurnal Pesisir dan Laut Tropis. 1(1):62-68.

Winarno, F.G. 1996. Teknologi Pengolahan Rumput Laut. Pustaka Sinar Harapan. Jakarta. 107 hal.

Zuccarello, G.C., Cricthley, A.T., Smith, J., Sieber, V., Lhonneur, G.B., West, J.A. 2006. Systematic and genetic variation in commercial Kappaphycus and Eucheuma (Solieriaceae, Rhodophyta). Journal of Applied Phycology. 18(3-5):643-651. 